\title{
Detection and molecular analysis of three exotic auger beetles of the genus Sinoxylon DUFTSCHMID, 1825 (Coleoptera: Bostrichidae) intercepted in Italy
}

\author{
MARCO BORIANI $^{*}$, ANDREA TADDEI ${ }^{1}$, MARCO BAZZOLI $^{2}$, \\ SERENA MiCHELOTTI ${ }^{2}$
}

\begin{abstract}
${ }^{1}$ Regione Lombardia, Servizio fitosanitario regionale, Laboratorio fitopatologico, c/o Fondazione Minoprio, Viale Raimondi 54, 22040 Vertemate con Minoprio (Como), Italy

${ }^{2}$ ERSAF, Servizio fitosanitario regionale, Via F. Baracca 33, 25128 Brescia, Italy
\end{abstract}

\begin{abstract}
Three exotic bostrichid beetle species - Sinoxylon anale, S. indicum and $S$. sudanicum - were simultaneously detected in Italy from wood packaging material declared compliant with the International Standard for Phytosanitary Measures No. 15 (ISPM 15) and originating from India. These taxa were identified through morphological characters and sequences of COX1 gene were obtained. This case study was analysed and the findings support the need to implement adequate wood requirements according to IPPC/FAO standards.
\end{abstract}

KEY WORDS: detection, exotic auger beetles, Sinoxylon anale, Sinoxylon indicum, Sinoxylon sudanicum, infested wood packaging, molecular analysis, India, Italy.

\section{INTRODUCTION}

On numerous occasions in international trade, Sinoxylon DUFTSCHMID, 1825 species have been detected in wood packaging material. Several species are regularly intercepted in many countries (RATTI \& RAMPINI 1977, PoGGi et al. 1994, Geis 2000, SAVOldelli \& Regalin 2009, ChaSe et al. 2012). The bostrichid genus Sinoxylon contains approximately 52 species, all of which are native to Asia, Africa and southern Europe,

\footnotetext{
* Corresponding author: marco_boriani@regione.lombardia.it
} 
where are typically not considered primary pests (BOROWSKI \& WĘGRZYNOWICZ 2007). Sinoxylon damage is normally caused by the boring of adults and larvae in the stems, branches, or twigs of dead, damaged, or stressed hosts (NAIR 2007). One species has even been known to damage lead cables (FILHO et al. 2006). Species of Sinoxylon are frequently intercepted in the U.S.A., representing 32\% of bostrichid interceptions between 1985 and 2000 (HAACK 2006, PRICE et al. 2011).

Three exotic bostrichid beetle species - Sinoxylon anale LESNE, 1897, S. indicum LESNE, 1897 and S. sudanicum LESNE, 1895 - were simultaneously detected in Italy in wood packaging material declared compliant with the International Standard for Phytosanitary Measures No. 15 (ISPM 15) and originating from India (Fig. 1).

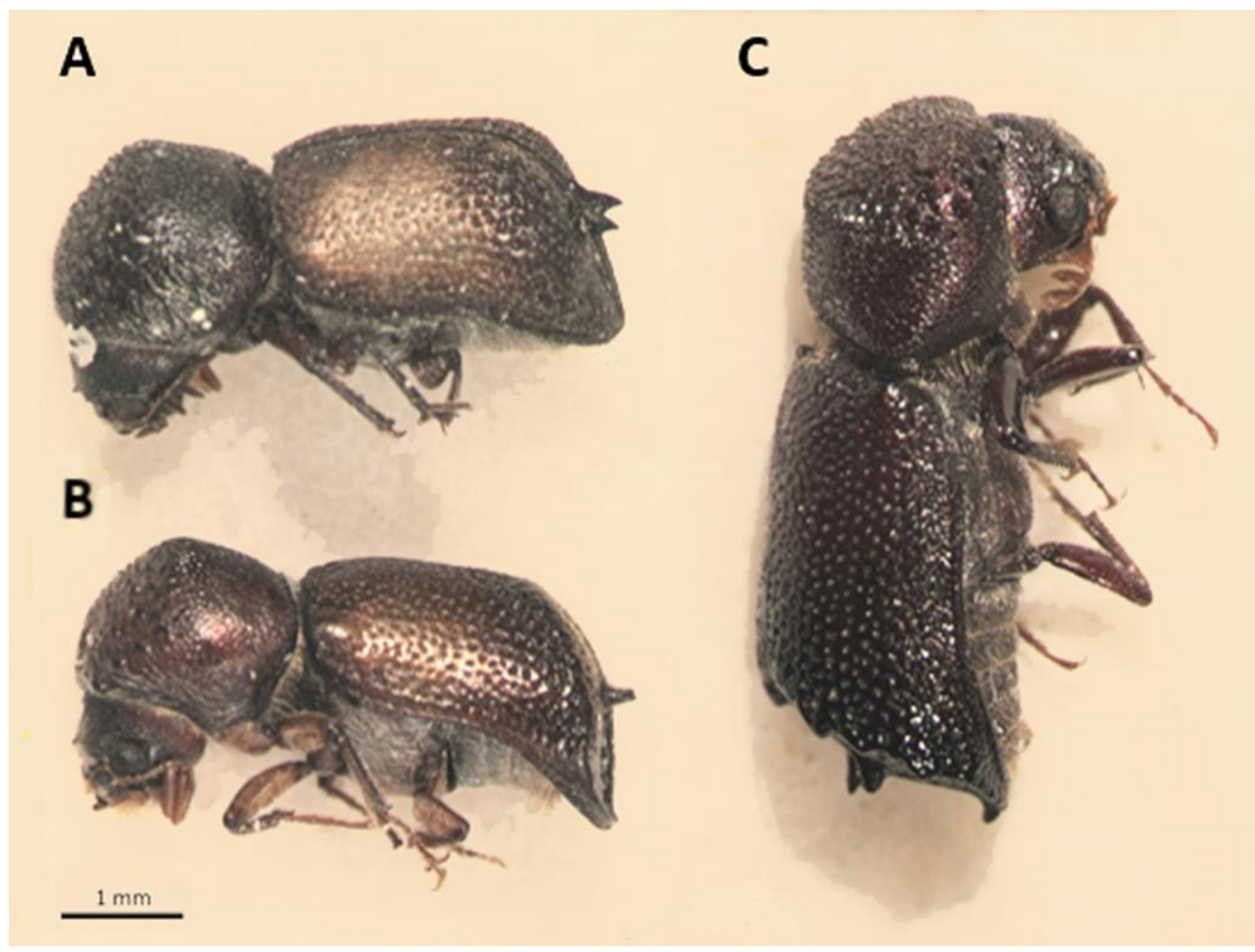

Fig. 1. Lateral views of Sinoxylon species intercepted in Villa Carcina (Brescia, Italy) during 2015. A) S. sudanicum; B) S. anale; C) S. indicum. Scale bar $=1.0 \mathrm{~mm}$.

Sinoxylon anale, considered one of the most destructive wood borers attacking a great variety of plants, is the economically most important and most commonly intercepted 
species of Sinoxylon (StEBbing 1914, Beeson 1941, Fisher 1950, ARgaman 1987, TEIXEIRA et al. 2002, SitTACHAYA et al. 2009, BEAVER et al. 2011). Described originally from India, this species has become almost cosmopolitan and has been introduced or intercepted in various parts of the world as a result of trading activities. It was recorded in wood packaging and in roots of Derris in the ports of New York, Detroit, Philadelphia, San Francisco, Miami and Columbus (LESNE 1906, FISHER 1950). ŚLIWA (1971) and SKALSKI (1971) registered the occurrence of $S$. anale in Poland, in material originating from Pakistan. ARGAMAN (1987) reported its occurrence in Tel Aviv (Israel). Joly et al. (1994) registered the occurrence of the species for the first time in South America, in Venezuela, in a packing box used for exporting fruits to the United States of America and TEIXERIA et al. (2002) collected $S$. anale in wood pallets coming from India and China. In Ukraine, GUMOVSKY (2010) recorded the species in wood pallets imported from India. A complete review of hosts of $S$. anale has been published by LYKIDIS et al. (2016).

Sinoxylon indicum has been intercepted in the United States in all shipments originating from India (CHASE et al. 2012) and within wood packaging material in Belgium (EPPO 2008) and Lithuania (EPPO 2015). It is reported to be a borer of fuel wood, military wooden tent-pins and the sapwood of dead wood (BEESON 1941, BHASIN \& RoONwAL 1954). BEESON (1941) listed these hosts: Acacia catechu (L.f.) WILlD., Adina cordifolia (RoXB.) BRANDIS, Anogeissus latifolia (ROXB. ex DC.) WALLICH ex BEDOME, Buchanania latifolia RoxB., Cassia siamea LAM., Dalbergia sissoo RoxB. ex DC., Mangifera indica L., Prosopis spicigera $(\mathrm{L}$.$) [ =$ P. cineraria (L.) DRUCE], Pterocarpus marsupium RoXB. and Zizyphus xylopyrus (RETZ.) WILLD. [as Z. xylopyra].

Sinoxylon sudanicum is best known as a destructive borer of wooden furniture (FLETCHER 1914, ANANTHAKRISHNAN 2004). It has been intercepted in Germany (GENTRY 1965, BoROWSKI \& WĘGRZYNOWICZ 2007), Italy (RATTI 2004) and in the United States (CHASE et. al. 2012). According to BEESON (1941) host plants includes Acacia arabica WILlD., Acacia gageana CRAIB., Albizzia lebbek (L.) BENTH., Albizzia procera (RoXB.) BENTH., Balanites roxburghii Planch., Bamboo (Bambusa sp. in Chatterjee \& Misra 1974), Butea frondosa RoxB. ex WILlD., Casuarina equisetifolia L., Dalbergia sissoo RoXB. ex DC., Ficus palmata ForssK., Mallotus philippinensis (LAM.) Muell. ARG., Mangifera indica L., Pongamia glabra Vent., Prosopis spicigera L., Quercus sp., Rhus parviflora ROXB., Shorea robusta GAERTN., Terminalia tomentosa (ROXB.) WIGHT \& AM. and several unidentified woods. Additionally, this species was reported from young fig trees (Ficus sp. L.) in Sudan (KING 1911), Sesbania grandiflora (L.) PERS. and Cambodia cotton (Gossypium hirsutum L.) in India (FLETCHER 1914).

This case study is analysed here and the necessity for the adequate implementation of wood requirements according to IPPC/FAO standards is also discussed (HAACK et al. 2014). 


\section{MATERIALS AND METHODS}

Wood packaging crates coming from Rajasthan, India, and arriving at a company in Villa Carcina (Brescia, Lombardy, Italy) in September 2015 were examined and found to be infested with exotic, unidentified beetles. Wood samples and live adult beetles were collected and analysed in the laboratory. At the same time, the remaining wood packaging was emptied, treated with an insecticide and subsequently destroyed. The beetles were identified using mainly the works of LESNE (1906), BADAWY \& NAGUIS (1961) and SitTichaYA et al. (2009). Identification through external morphological characters was integrated by molecular analysis. The nomenclature follows BOROWSKI \& WĘGRZYNOWICZ (2007).

The imported goods had travelled by ship and truck. They were kept in wooden support forms with a pallet as a base, current axes fixed with metal studs, overlapping support (without attachment) and then fixed with axis (sawn wood of various types and essences) uprights, which closed the upper and lower ends of two plywood panels (Fig. 2).

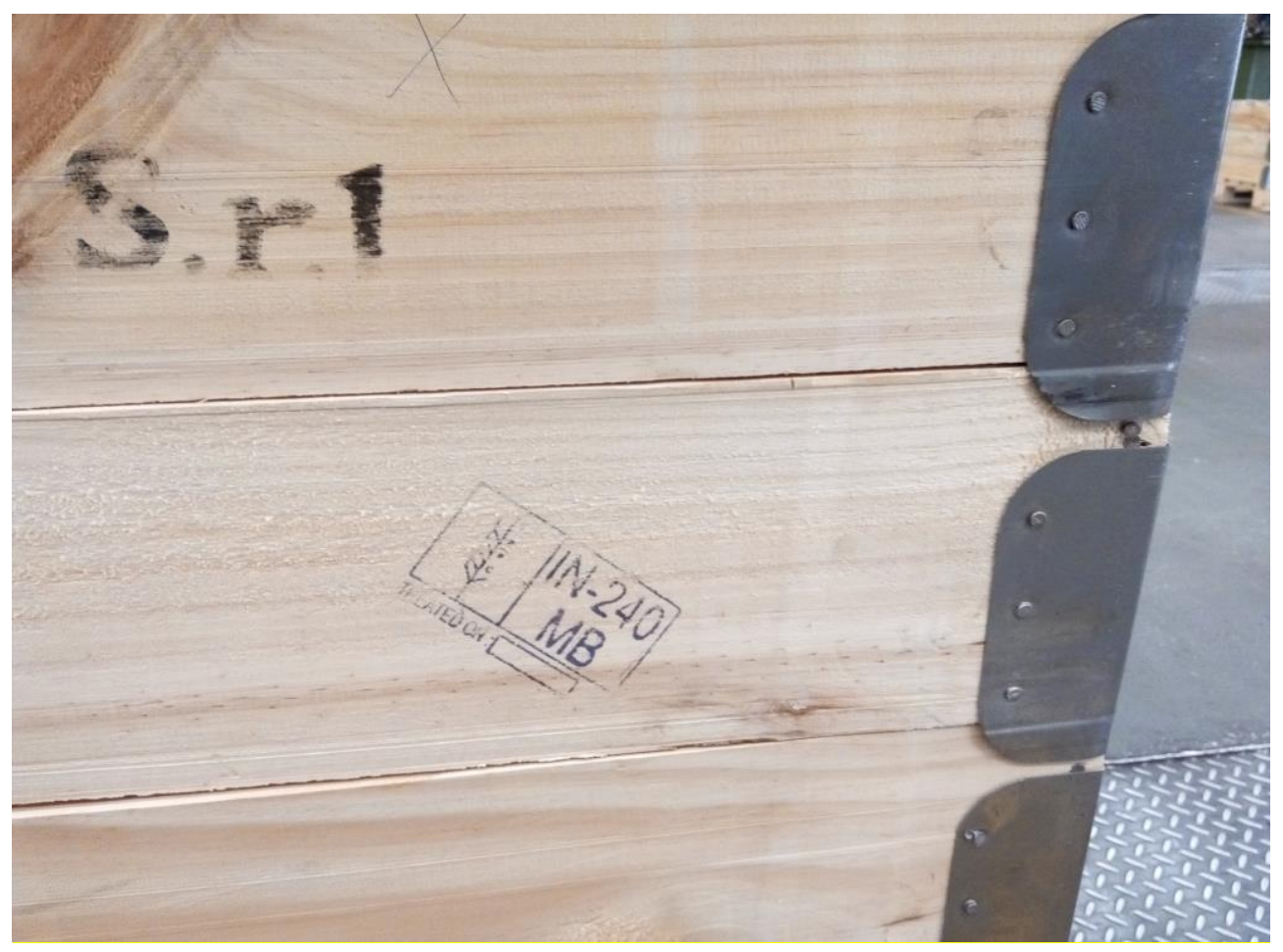

Fig. 2. Detail of the wood packaging crate, in compliance with and certified according to ISPM 15. 
On some cases, there were no markings while on others the IPPC/FAO mark was present on some sides (sawn), but otherwise never on pallets or on sawn minor wood pieces (Fig. 3).

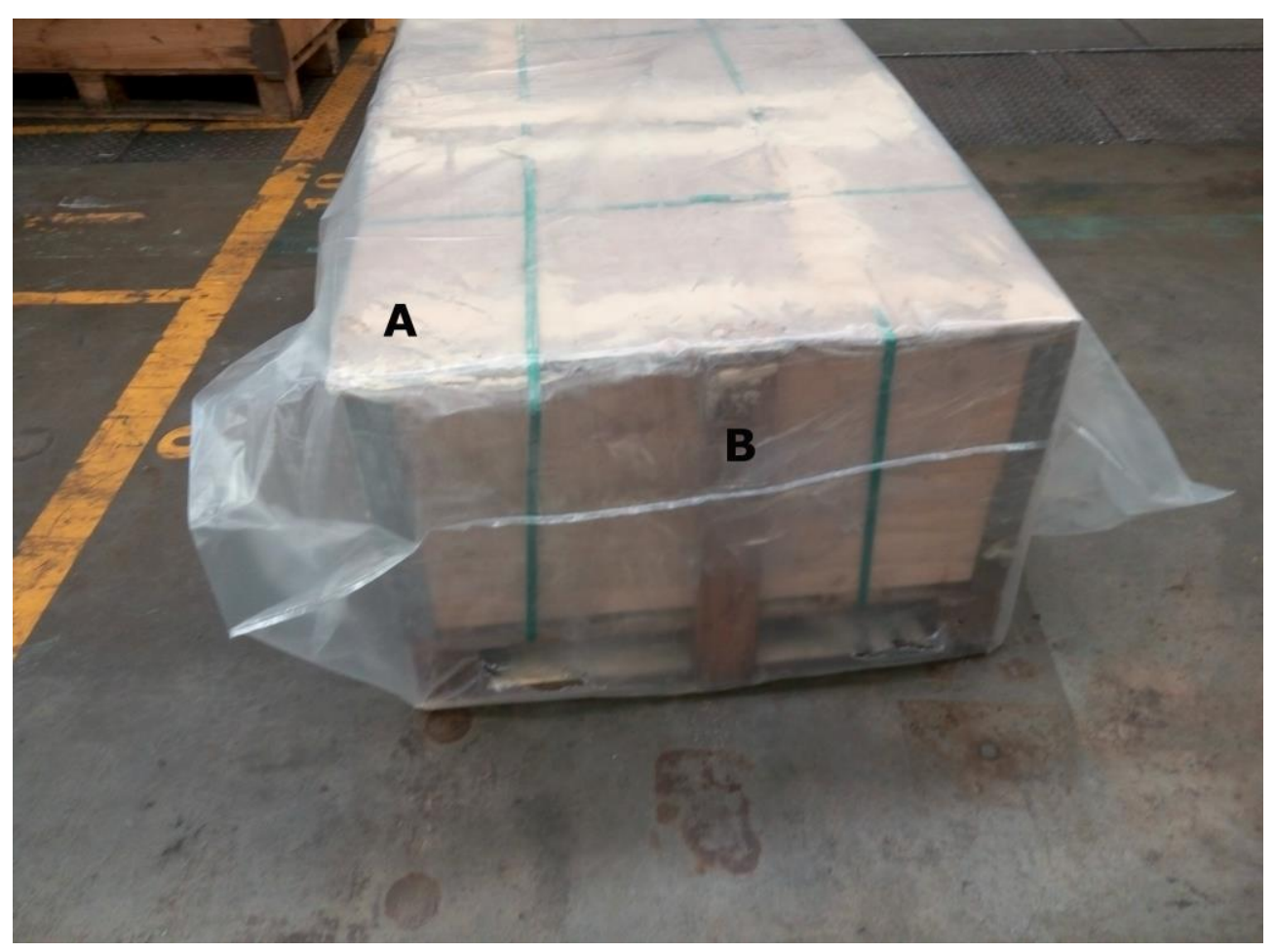

Fig. 3. (A) Added uncertified material placed over the crate as a cover. Note the central upright axis does not conform either (B).

All 25 cases were isolated in a corner of the warehouse, sealed and wrapped in a cloth and in cellophane as soon as the infestation was detected in order to prevent contamination of other types of wood packaging in the area (Fig. 4).

The merchandise had travelled inside a sealed container with no other merchandise present. The container was opened and the contents were off-loaded for handling by the aforesaid company. Large quantities of sawdust and numerous beetles were found in the cloth used for wrapping the crates. Upon inspection, the woody material contained insectcaused tunnels and holes. Sinoxylon anale was the most numerous species, while smaller 


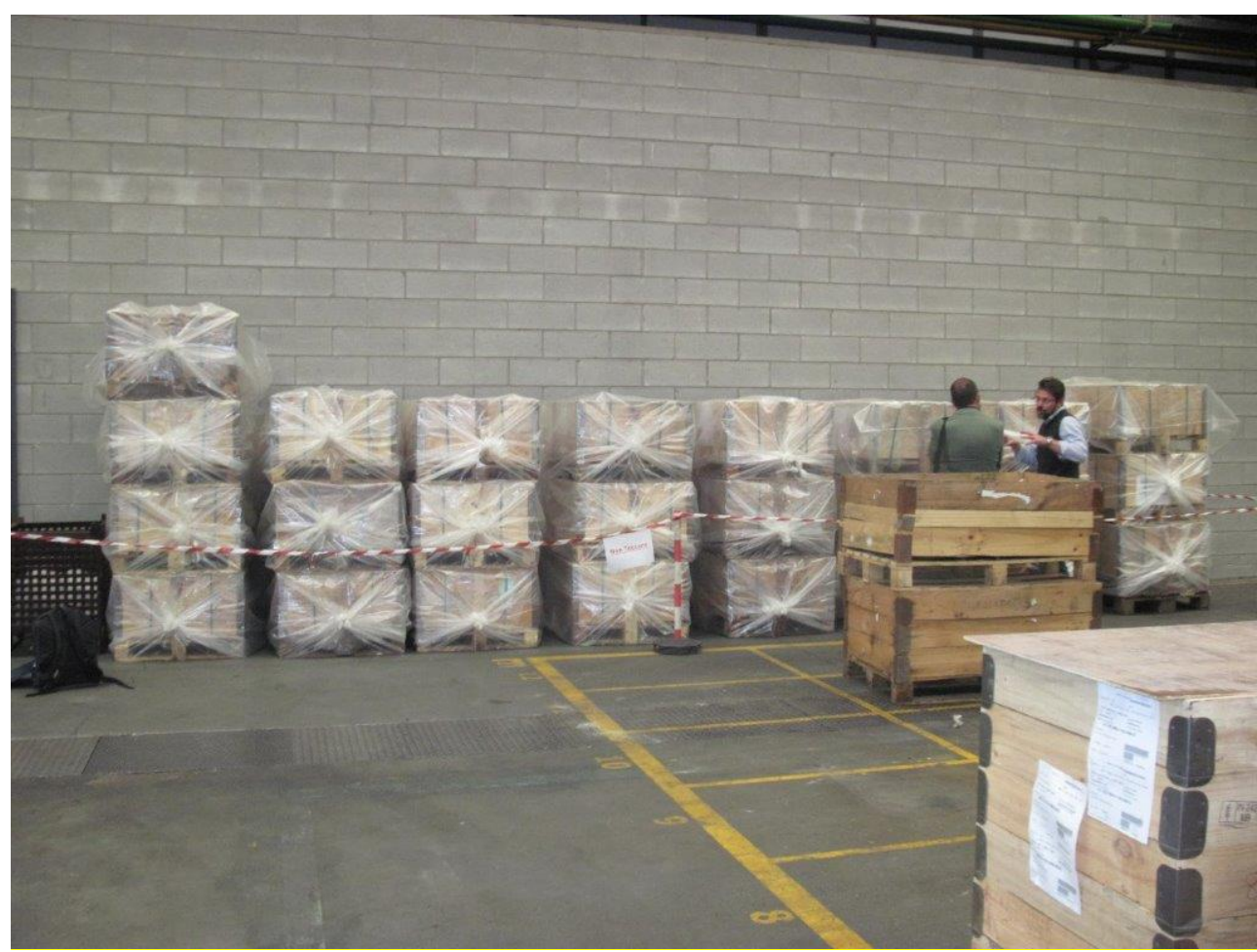

Fig. 4. Cases isolated in a corner of the warehouse, sealed and wrapped in a cloth and in cellophane.

numbers of S. indicum and S. sudanicum were found. Samples of insects and wood were taken. The inspection also covered all the areas where the crates were stored. No signs of the presence of beetles were found anywhere else on the company's premises.

During the inspection, the purchase invoice was acquired to identify the origin of the goods, travel insurance and waybill in order to find out the means of transport of the crates (container, ship, truck), their path and the customs certification identifying the point of entry into the European Union. Phytosanitary measures No. 0769-10.IX.2015 were issued requiring: a) proper insecticide treatment for the surface pest control of the contaminated material, transportation to a site of destruction without the risk of the insects spreading to surfaces and wood packaging in the vicinity of the affected crates. Pest control was scheduled for September $11^{\text {th }} 2015$; b) the destruction of all 25 wooden crates from India was to take place via combustion within 15 days. On October $2^{\text {nd }} 2015$ the effective enforcement of the phytosanitary measures ordered was verified. 


\section{MOLECULAR ANALYSIS}

Overall ten specimens of the three different Sinoxylon species collected were submitted for molecular analysis. The other specimens are stored at the Regional Plant Health Service Laboratory c/o Fondazione Minoprio. DNA was purified through Zymo Tissue \& Insect Miniprep Kit (Zymo Research Corporation, Irvine, CA), after specimens were disrupted by means of Tissue Lyser (Qiagen). The primer pair LepF1/LepR1 (HEBERT et al. 2004) was used for amplifying part of the mitochondrial cytochrome oxidase gene, subunit 1 (COX1). The PCR mix had a total volume of $25 \mu 1$ and contained $3 \mathrm{mM} \mathrm{MgCl}_{2}$, each primer at a concentration of $400 \mathrm{nM}, 0,4 \mathrm{mM}$ dNTPs, $1 \mu \mathrm{l}$ of genomic DNA, and 1 unit of TaqDNA polymerase (GoTaq G2 Flexi, Pro). The thermocycling profile consisted of one cycle of $1 \mathrm{~min}$ at $94^{\circ} \mathrm{C}$, six cycles of $1 \mathrm{~min}$ at $94^{\circ} \mathrm{C}, 1 \mathrm{~min}$ and $30 \mathrm{sec}$ at $45^{\circ} \mathrm{C}$, and $1 \mathrm{~min}$ and $15 \mathrm{sec}$ at $72^{\circ} \mathrm{C}$, followed by 36 cycles of $1 \mathrm{~min}$ at $94^{\circ} \mathrm{C}, 1 \mathrm{~min}$ and $30 \mathrm{sec}$ at $51^{\circ} \mathrm{C}$, and $1 \mathrm{~min}$ and $15 \mathrm{sec}$ at $72^{\circ} \mathrm{C}$, with a final step of $5 \mathrm{~min}$ at $72^{\circ} \mathrm{C}$. The amplification products were sent for Sanger sequencing using the forward primer LepF1 (GATC Biotech, Köln). Sequences were edited with BioEdit v.7.2.5.0 (HALL 1999).

Sequences were blasted against the complete sequence database of BOLD data systems in order to investigate the closest matches (http://www.boldsystems.org).

Sequences having no matches on BOLD were blasted against the complete sequence database of GenBank (https://blast.ncbi.nlm.nih.gov/Blast.cgi). Haplotype and nucleotide diversity were calculated using DNASP5.10. Genetic distances between species were measured and the Neighbour Joining Tree was built using Kimura 2-parameter distance model (MEGA v.7.0).

The sequences obtained in this study were submitted to the GenBank database (Accession Numbers: Sinoxylon anale LT904778-LT904781 ${ }^{1}$, S. indicum LT934415LT934416, S. sudanicum LT934421-LT934424). They represent the first DNA barcoding sequences for Sinoxylon indicum and S. sudanicum species available in international genetic databases.

${ }^{1}$ During this study, Gianluca NARDI (Centro Nazionale per lo Studio e la Conservazione della Biodiversità Forestale "Bosco Fontana" Carabinieri, Marmirolo (MN), Italy) sent us three specimens intercepted in Greece and originating from China (LIKTIDIS et al. 2016). Only one specimen was successfully analysed. The haplotype was identical to LT904780. 


\section{RESULTS}

A 583 bp-long fragment of the cytochrome oxidase gene, subunit 1 (COX1), was obtained for each of the ten specimens processed. Within every Sinoxylon species, the sequences showed that all the specimens belonged to different haplotypes $(\mathrm{H}-$ unique haplotypes), as could be inferred from the haplotype diversity values (Hd), all equal to 1 . The nucleotide diversity $(\Pi)$ within species ranged from $0.29 \%$ (STD \pm 0.0008 ) to $0.86 \%$ (STD \pm 0.004 ), reflecting differences among the haplotypes (Table 1). Polymorphic sites ranged from 3 to 5 among sequences within a species.

Table 1. Haplotype and nucleotide diversity. Ns - number of sequences, Fl - fragment length (bp), Ps - polymorphic sites.

\begin{tabular}{lccccccc}
\hline \multicolumn{1}{c}{ Species } & Ns & Fl & H & Ps & Hd & П & 土 STD \\
\hline Sinoxylon indicum & 2 & 583 & 2 & 5 & 1 & 0.00858 & 0.00429 \\
Sinoxylon anale & 4 & 583 & 4 & 3 & 1 & 0.00286 & 0.00076 \\
Sinoxylon sudanicum & 4 & 583 & 4 & 5 & 1 & 0.00429 & 0.00087 \\
\hline
\end{tabular}

The genetic distances between the species ranged from 17 to $19 \%$, suggesting that the three Sinoxylon species are remarkably different from the evolutionary point of view (Table 2).

Table 2. Genetic distances between species.

\begin{tabular}{lccc}
\hline & Sinoxylon indicum & Sinoxylon anale & Sinoxylon sudanicum \\
\hline Sinoxylon indicum & - & $(0.0194)^{*}$ & $(0.0189)^{*}$ \\
Sinoxylon anale & 0.1682 & - & $(0.0189)^{*}$ \\
Sinoxylon sudanicum & 0.1896 & 0.1746 & - \\
\hline
\end{tabular}

*standard error

The Neighbour Joining Tree (Fig. 5) showed that the taxa cluster in three major groups, representing the three Sinoxylon species as identified by the morphological analysis (bootstrap test 1000 replicates). A corresponding COX1 sequence of Anthicus antherinus (LINNAEUS, 1761) (Coleoptera: Anthicidae) was chosen as an outgroup from the GenBank database. 


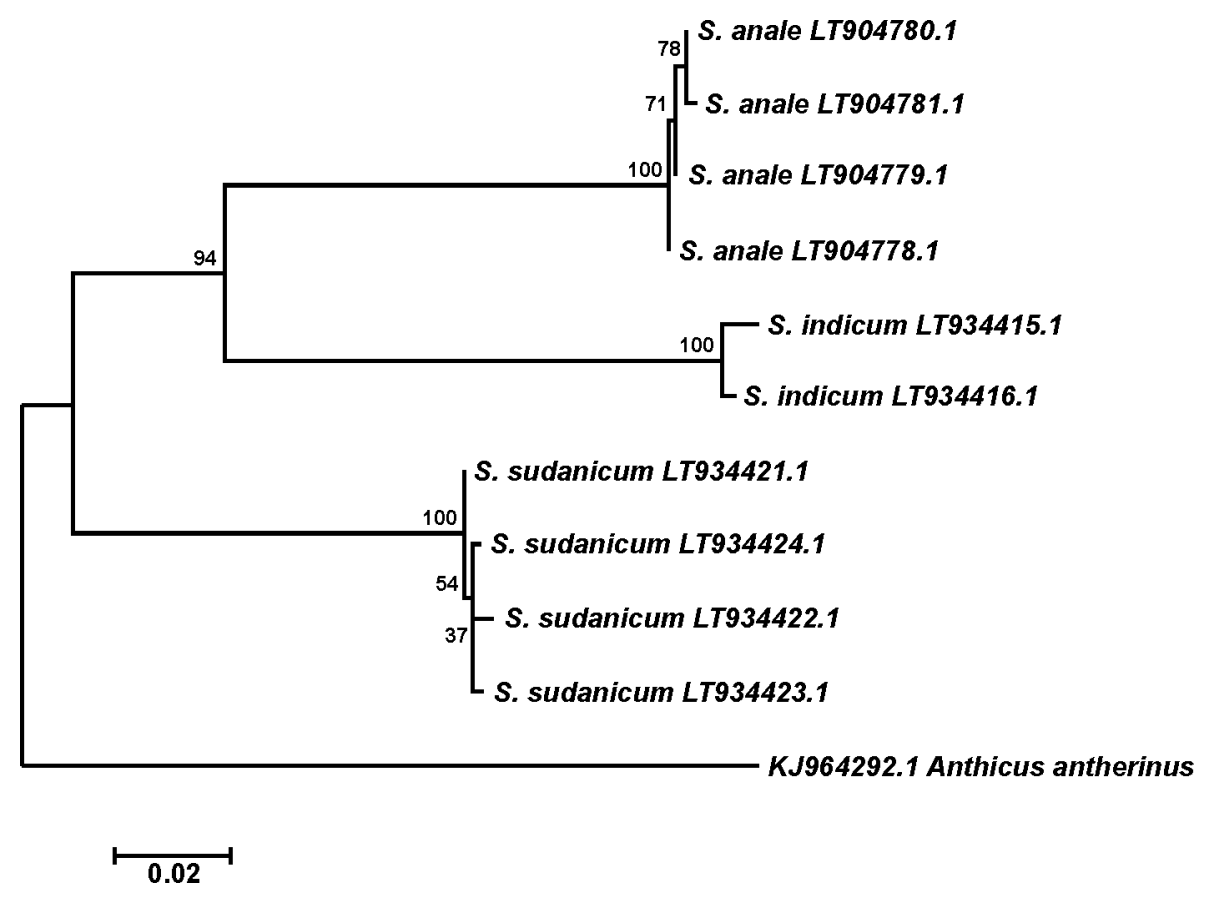

Fig. 5. Neighbour Joining Tree (MEGA v.7.0, Kimura 2-parameter method, bootstrap test 1000 replicates, outgroup KJ964292.1 Anthicus antherinus).

\section{DISCUSSION AND CONCLUSIONS}

Three exotic bostrichid beetle species, Sinoxylon anale, S. indicum and S. sudanicum, were simultaneously infesting wood packaging material shipped from India to Italy. The molecular data showed that each of the ten specimens analysed belonged to a different haplotype, i.e. ten unique haplotypes. This genetic diversity could have been derived from a certain level of admixtures of the Sinoxylon spp. populations at the sites where the packaging was assembled and/or stored before shipment. At those sites, the wood material is probably accumulated from different areas of the country, generating populations with a not negligible level of genetic diversity. This feature could enhance the invasive power of a founding population when accidentally introduced in an area where the species is not native.

These exotic Sinoxylon species are common in tropical forests, timber depots, sawmills and furniture building factories, and are primary borers in the sapwood of logs and timber used in houses, boxes and packing cases. They are found on numerous occasions in wood packaging material coming mainly from India and which are reportedly treated according to 
ISPM 15 (KREHAN 2007, BENKER 2008, ChASE et al. 2012). The known host plants are only tropical species and the climate in Europe is not expected to be suitable for beetle establishment. However, the possibility that some species may become adapted in Mediterranean regions cannot be ruled out.

The main causes of non-compliance of ISPM 15 in India are considered to be pest resistance to treatment, failed treatment and the inappropriate use of the mark (GAUTAM 2014).

In this case study, the wood packaging material was certified IPPC/FAO and accompanied by the prescribed mark. However, on some crates there was no mark, while on others it was present only on some sides. Even so, marks were never found on pallets and on sawn timber of minor dimensions, clearly obtained from other sources. It was evident that there were extraneous packaging pieces nailed to certified material. The origin of the infestation seemed to come from these pieces of foreign wood, but the beetles had spread easily even to the certified wood.

The intention of ISPM 15 is that once the WPM has been treated and officially marked, the treatment does not expire. Wood packaging made from exempt materials, but combined with solid wood components, must always be treated and marked. Therefore, marked WPM can be reused without requiring new treatment or new marking. Regardless of this, when the marked wood packaging material is repaired or remanufactured, only wood complying with this standard should be used. Otherwise such non-compliance may have disagreeable consequences and compromise the application of ISPM 15.

\section{ACKNOWLEDGEMENTS}

We would like to thank Wisut SitTichaYA (Prince of Songkla University, Hat Yai, Songkhla, Thailand) for confirming the identity of Sinoxylon sudanicum, Jerzy BOROWSKI (University of Life Sciences SGGW, Warsaw, Poland) and Andrea GaLIMBERTI (University of Milan - Bicocca, Department of Biotechnology and Bioscience, Milan, Italy) for them critical reading of the paper. We are also grateful to C. Richard EDWARDS (Purdue University, West Lafayette, USA) for linguistic corrections. Special thanks go to Gianluca NARDI (Centro Nazionale per lo Studio e la Conservazione della Biodiversità Forestale "Bosco Fontana" Carabinieri, Marmirolo (MN), Italy) for sending us some specimens of Sinoxylon anale originating from China to compare. 


\section{REFERENCES}

ANATHAKRISHnAn T.N. 2004. General and Applied Entomology. $2^{\text {nd }}$ ed. Tata Mc Graw-Hill, New Delhi.

ARGAMAN Q. 1987. Sinoxylon anale - a new destructive wood borer in Israel. Phytoparasitica, 15 (3): 257.

Badawy A., Naguib F. 1961. External morphology of the adult Sinoxylon sudanicum LeSNe (Coleoptera: Bostrichidae). Bulletin de la Société entomologique d'Egypte, 45: 223-243.

Beaver R.A., Sittichaya W., Liu L.-Y. 2011. A review of the Powder-Post Beetles of Thailand (Coleoptera: Bostrichidae). Tropical Natural History, 11 (2): 135-158.

BEESON C.F.C. 1941. The ecology and control of the forest insects of India and the neighbouring countries. Jaswant Singh Vasant Press, Dehra Dun.

BenKer U. 2008. Stowaways in Wood Packaging Material - Current Situation in Bavaria. Forstschutz Aktuell, 44: 30-31.

Bhasin G.D., Roonwal M.L. 1954. A list of insect pests of forest plants in India and the adjacent countries. Indian Forest Bulletin, 171 (9): 5-93

Borowski J., WęGrzynowicz P. 2007. World Catalogue of Bostrichidae (Coleoptera). Mantis Publishing, Olsztyn.

Chase K.D., SChierfer T.L., Riggins J.J. 2012. First incidence of Sinoxylon indicum and Sinoxylon sudanicum (Coleoptera: Bostrichidae) in Mississippi. Florida Entomologist, 95 (3): 767-770.

ChATTERJEe P.N., MisRa M.P. 1974. Natural insects enemy and plant host complex of forest insects pest of Indian region. Indian Forest Bulletin, 265: 1-233.

EPPO [European and Mediterranean Plant Protection Organization] 2008. EPPO report on notifications of non-compliance. EPPO Reporting Service No.9 Num. article: 2008/187.

EPPO [European and Mediterranean Plant Protection Organization] 2015. EPPO report on notifications of non-compliance. EPPO Reporting Service No.1 Num. article: 2015/12.

FISHER W.S. 1950. A revision of the North American species of beetles belonging to the family Bostrichidae. Miscellaneous publication United States Department of Agriculture No. 698, Washington, D.C.

FLETCHER T.B. 1914. Some south Indian insects and other animals of importance, considered especially from an economic point of view. Superintendent, Government Press, Madras, India.

GaUTAM V. 2014. India. [in:] A workshop on the implementation of the International Standard for Phytosanitary Measures (ISPM) 15, Regulation on wood packaging in international trade was held in Beijing, China from June 10 to 14, 2014, 12.

GEIS K.-U. 2000. Timber infesting species of Col. Lyctidae and Bostrichidae imported into Germany since ca. 1985. International Research Group on Wood Preservation, Report of Section 12000 , IRG/WP 00-10385.

GentRy J.W. 1965. Crop insects of northeast Africa southwest Asia. Agriculture Handbook No. 273. Agricultural Research Service, United States Department of Agriculture, Washington, D.C. 
GumOvsky A.V. 2010. A record of Sinoxylon anale LESNE in Ukraine with notes on false powderpost beetles (Coleoptera: Bostrichidae) and their chalcidoid parasitoids (Hymenoptera). Ukrainska Entomofaunistyka, 1 (2): 1-8.

HAACK R.A. 2006. Exotic bark and wood-boring Coleoptera in the United States: recent establishments and interceptions. Canadian Journal of Forest Research, 36 (2): 269-288.

Haack R.A., Britton K.O., Brockerhoff E.G., Cavey J.F., Garrett L.J., Kimberley M., Lowenstein F., Nuding A., Olson L.J., TuRner J., Vasilaky K.N. 2014. Effectiveness of the International Phytosanitary Standard ISPM No. 15 on Reducing Wood Borer Infestation Rates in Wood Packaging Material Entering the United States. PLoS ONE, 9 (5): e96611.

HALL T.A. 1999. BioEdit: a user-friendly biological sequence alignment editor and analysis program for Windows 95/98/NT. Nucleic Acids Symposium Series No. 41: 95-98.

Hebert P.D.N., Penton E.H., Burns J.M., Janzen D.H., Hallwachs W. 2004. Ten species in one: DNA barcoding reveals cryptic species in the neotropical skipper butterfly Astrapes fulgerator. Proceedings of the National Academy of Sciences of the United States of America, 101 (41): 14812-14817.

KING H.H. 1911. Report of the entomological section of the Wellcome Tropical Research Laboratories. [in:] A. BALFOUR (ed.). Fourth Report of the Wellcome Tropical Research Laboratories at the Gordon Memorial College, Khartoum, Vol. B: General Science. Balliere, Tindall and Cox, London, 95-150

KREHAN H. 2007. Verpackungsholz-Kontrollen in Österreich notwendiger denn je. Forstaktuell, 41: $2-4$.

ISPM 15. 2009. Regulation of wood packaging material in international trade. Rome, IPPC, FAO.

Joli L.J., Dedordy J., Moreira M. 1994. Sinoxylon anale Lesne, 1897 (Coleoptera, Bostrichidae) neuvo restro para la fauna Venezolana. Boletín de Entomología Venezolana NS, 9 (1): 21-24.

LESNE P. 1906. Révision des Coléoptères de la famille des Bostrychides. $5^{\text {ème }}$ Mémoire. Sinoxylinae. Annales de la Société entomologique de France, 75: 445-561.

LiU L.-Y., SCHÖNITZER K., YANG J.-T. 2008. A review of the literature on the life history of Bostrichidae. (Coleoptera). Mitteilungen der Münchner Entomologischen Gesellschaft, 98: 91-97.

Lykidis C.T., NARDi G., Petrakis P.V. 2016. First record of Sinoxylon anale and S. unidentatum in Greece, with an updated account on their global distribution and host plants (Coleoptera: Bostrichidae) Fragmenta entomologica, 48 (2): 101-121.

NAIR K.S.S. 2007. Tropical Forest Insect Pests: Ecology, Impact, and Management. Cambridge University Press, Cambridge, UK.

Poggi R., Brussino G., SCARpelli F. 1994. Intercettazione in Piemonte di Sinoxylon conigerum Gerstacker (Coleoptera: Bostrichidae). [in:] F. FrILLI (ed.). Atti XVII Congresso nazionale italiano di Entomologia, Udine 13-18 giugno 1994. Arti Grafiche Friulane, Udine, 217-219.

Price T., Brownell K.A., Raines M., Smith C.L., Gandhi K.J.K. 2011. Multiple detections of two exotic auger beetles of the Genus Sinoxylon (Coleoptera: Bostrichidae) in Georgia, USA. Florida Entomologist, 94 92): 354-355.

RAtTi E. 2004. Coleoptera Lyctidae e Bostrichidae intercettati nel porto e negli ambienti urbani di Venezia. Bollettino del Museo Civico di Storia Naturale di Venezia, 55: 121-125. 
RatTi E., RAmpini L. 1977. Risultati di alcuni controlli fitosanitari nel porto di Venezia. 1 - La coleotterofauna associata ai rizomi di manioca importati dall'Africa meridionale (Coleoptera). Lavori - Società Veneziana di Scienze Naturali, 2: 30-34.

SAVOLDELli S., Regalin R. 2009. Infestation of wood pallets by Sinoxylon unidentatum (FABRICIUS) (Coleoptera: Bostrichidae) in Italy. Bollettino di Zoologia Agraria e di Bachicoltura ser II, 41 (3): 235-238

SitTichaya W.B., Beaver R.A. Liu L.-Y., NgampongSai A. 2009. An illustrated key to powder post beetles (Coleoptera, Bostrichidae) associated with rubberwood in Thailand, with new records and a checklist of species found in southern Thailand. Zookeys, 26: 33-51.

SKALSKI J. 1971. Sinoxylon anale LESNE - a newcomer from Pakistan. Przemysł Drzewny, 22: 34-35. [in Polish]

ŚLIWA E. 1971. Sinoxylon anale LESNE - a pest brought from Pakistan to Poland. Sylwan, 115: 51-54. [in Polish]

STEBBiNG E.P. 1914. Indian Forest Insects of Economic Importance: Coleoptera. Eyre and Spottiswoode Ltd., London, UK.

TeiXeIRa É.P., Novo J.P.S., BerTi Filho E. 2002. First record of Sinoxylon anale LeSNe and Sinoxylon senegalensis (KARSCH) (Coleoptera: Bostrichidae) in Brazil. Neotropical Entomology, 31 (4): 651-652.

Received: 21 March 2018

Accepted: 26 September 2018 